\title{
ANALISIS EFISIENSI DAN KELEMBAGAAN PEMASARAN JAGUNG DI KABUPATEN BENGKAYANG
}

\section{The Analysis of Efficiency and Institution of Corn Marketing in Bengkayang Regency}

\author{
Jajat Sudrajat ${ }^{1}$, Jangkung Handoyo Mulyo ${ }^{2,3}$, Slamet Hartono ${ }^{2}$, Subejo ${ }^{2}$ \\ ${ }^{1}$ Dosen Jurusan Agribisnis Fak. Pertanian Univ. Tanjungpura, Pontianak \\ ${ }^{2}$ Dosen Jurusan Ekonomi Pertanian Fak. Pertanian, Univ. Gadjah Mada, Yogyakarta \\ ${ }^{3}$ Pusat Studi Kependudukan dan Kebijakan, Univ. Gadjah Mada, Yogyakarta
}

\section{ABSTRACT}

This research aim is to analyze the efficiency and institution of corn marketing. The study is done by using survey method. Primary data are collected comprises 122 household's farmers which are randomly selected. Meanwhile, there are nine traders selected by purposive sampling based on information of the farmer. The result of this research concluded some important informations, as follow: (a) the relationships among institutions of corn marketing is frequent based on the implementation of social value and norm (social capital) which is important role in improving efficiency and efectivity of whole institutional marketing, (b) based on whole (totality) of cost and benefit analyze which is obtained on each marketing institution, it can be concluded that the corn marketing has been done enough efficient. This reality can be shown by farmer's share of corn price which is enough big that is 76.92 percent and the fact that every marketing institution has got logical benefit which is appropriate with its role.

Keywords: efficiency, institution, social capital, farmer's share

\section{PENDAHULUAN}

Jagung telah menjadi komoditas utama untuk pengembangan ekonomi perdesaankhususnya di Kecamatan Tujuh Belas, Kabupaten Bengkayang Provinsi Kalimantan Barat. Pengembangan tanaman jagung yang dimulai sejak tahun 1990-an dinilai oleh banyak pihak telah membawa perubahan berarti bagi peningkatan kesejahteraan petani. Arti penting komoditas jagung menurut Burhansyah (2006) untuk petani di wilayah ini tercermin dari luas tanaman yang mencapai 10.000-an hektar (46,26\%) dari total lahan potensial seluas 21.619 hektar. Hal ini selaras dengan data BPS (2013) mengenai perkembangan luas tanam jagung sebagaimana terlihat pada Tabel 1.

Tabel 1. Perkembangan Luas Panen, Produksi, dan Produktivitas Tanaman Jagung di Kecamatan Tujuh Belas Kabupaten Bengkayang.

\begin{tabular}{ccccc}
\hline No & Tahun & $\begin{array}{c}\text { Luas Panen } \\
(\mathrm{Ha})\end{array}$ & $\begin{array}{c}\text { Produksi } \\
\text { (Ton) }\end{array}$ & Produktivitas (Ton/Ha) \\
\hline 1 & 2007 & 10112 & 55,07 & 5,45 \\
2 & 2008 & 9235 & 56,47 & 6,11 \\
3 & 2009 & 4615 & 26,52 & 5,75 \\
4 & 2010 & 9933 & 42,68 & 4,30 \\
5 & 2011 & 7352 & 29,97 & 4,10 \\
6 & 2012 & 9042 & 39,31 & 4,35 \\
\hline
\end{tabular}


Keberhasilan pengembangan komoditas jagung, tidak terlepas dari berbagai faktor yang mendukungnya, yaitu: Pertama, kondisi sumberdaya alam yang sangat potensial untuk budidaya tanaman jagung mencakup jenis tanah latosol yang subur, curah hujan yang merata sepanjang tahun (rata-rata 14 hari hujan/bulan), dan intensitas penyinaran matahari yang cukup banyak sebab berada di daerah khatulistiwa (BPS, 2013). Kedua, tersedianya sistem kelembagaan pemasaran yang terjalin secara alamiah dan harmonis antara petani dengan pedagang pengumpul jagung (pedagang desa). Kedua aspek di atas telah membawa semangat dan motivasi kepada petani untuk melakukan aktivitas usahatani secara lebih baik. Keberhasilan pada usahatani jagung disinyalir telah menjadi pendorong berkembangnya usahatani pada berbagai komoditas lainnya yaitu perkebunan karet rakyat, sayuran, usaha ternak sapi, dll. Namun demikian, keberhasilan pada usahatani jagung ini dengan sistem kelembagaan pemasaran yang ada masih perlu dibuktikan apakah saluran pemasaran yang tercipta telah benar-benar berjalan secara efisien ?. Sebab besarnya jumlah produksi dan meluasnya aktivitas usahatani jagung belum menjadi jaminan mencerminkan sistem pemasaran yang efisien, terutama dilihat dari keuntungan yang diterima petani.

Analisis efisiensi pemasaran secara umum sering dipergunakan untuk menilai kinerja suatu aktivitas pemasaran.Suatu aktivitas pemasaran dikatakan baik apabila pelaksanaan pemasaran telah berlangsung secara efektif dan efisien. Ciri suatu pemasaran telah belangsung efisien menurut Mubyarto (1989) adalah apabila kondisi dua aspek telah dipenuhi, yaitu: Pertama, dapat menyampaikan hasil produksi dari petani produsen kepada konsumen dengan biaya yang paling murah. Kedua, mampu mengadakan pembagian harga yang adil dari keseluruhan harga yang dibayarkan oleh konsumen akhir kepada semua pihak yang terlibat dalam kegiatan produksi dan pemasaran komoditas tersebut.

Pada sisi lainnya, efisiensi suatu pemasaran sesungguhnya diyakini pula tidak hanya ditentukan oleh aspek-aspek ekonomi semata, namun juga ditentukan oleh aspek-aspek yang bersifat non ekonomi atau aspek sosial kelembagaan yang banyak mewarnai transaksi di negara-negara berkembang seperti Indonesia. Berkaitan dengan aspek kelembagaan ini, aktivitas ekonomi yang terjadi sering kali terlihat menyimpang dari aspek teori ekonomi murni. Penyimpangan ini banyak terjadi karena faktor-faktor yang bersifat sosiologis yang banyak mempengaruhi perilaku ekonomi di masyarakat negara berkembang. Kelembagaan ekonomi yang terjadi dalam pemasaran barang dan jasa sering kali terlihat berbeda dengan logika ekonomi sehingga pada gilirannya akan mempengaruhi tingkat harga yang terjadi di pasar. Pemasaran komoditas pertanian yang banyak melibatkan para pedagang desa merupakan contoh nyata bagaimana tersusunnya aktivitas ekonomi petani di perdesaan sehingga produksi pertanian dapat berlangsung serta kestabilan ekonomi petani dapat dipertahankan.

Oleh karena itu, penelitian ini dimaksudkan untuk mencapai tujuan sebagai berikut: (a) Menganalisis efisiensi saluran pemasaran jagung di Kabupaten Bengkayang, (b) Menganalisis peran aspek kelembagaan dalam pemasaran jagung di Kabupaten Bengkayang. Berdasarkan pada lingkup studi tersebut, maka penelitian ini diharapkan dapat memberikan informasi kepada instansi terkait dalam penentuan arah kebijakan untuk meningkatkan efisiensi dan efektivitas pemasaran jagung.

\section{METODE PENELITIAN}

\section{Metode Dasar}

Penelitian dilakukan dengan menggunakan metode deskriptif analitis dengan menerapkan pendekatan gabungan yaitu antara pendekatan kuantitatif dan kualitatif. Pada 
kajian ini, pendekatan kuantitatif diperlukan untuk menanalisis data-data yang bersifat kuantitatif seperti dengan melakukan analisis marjin, analisis share harga, dll. Sementara itu, pendekatan kualitatif diperlukan untuk mengungkapkan data dan fakta lapangan yang bersifat kualitatif (kelembagaan). Dengan demikian, dalam batas tertentu penelitian ini pada dasarnya menggunakan pendekatan campuran (mixed method).

\section{Lokasi Penelitian}

Penelitian dilaksanakan di Wilayah Kabupaten Bengkayang yang dikategorikan sebagai wilayah dataran tinggi di Kalimantan Barat serta merupakan wilayah perbatasan Indonesia-Malaysia. Pemilihan sampel kecamatan ditentukan secara sengaja (non probability sampling), yaitu teknik pengambilan sampel dengan kaidah tidak semua individu dalam populasi memiliki peluang yang sama untuk dipilih menjadi sampel. Kecamatan terpilih dalam penelitian ini adalah Kecamatan Tujuh Belas dengan pertimbangan daerah ini memiliki luas tanam komoditas jagung terluas di Kabupaten Bengkayang.

\section{Metode Pengumpulan Data}

Pengumpulan data pada studi ini terdiri dari dua bagian yaitu pengumpulan data usahatani pada level petani dan pengumpulan data yang berhubungan dengan para pedagang dalam pemasaran jagung. Pengumpulan data usahatani dilakukan secara acak sederhana (simple random sampling) dari keseluruhan populasi yang ada di lokasi penelitian. Jumlah sampel dalam studi terdiri dari 122 rumah tangga petani. Sementara itu, untuk melihat efisiensi pemasaran, para pedagang yang diwawancarai terdiri daritujuh pedagang pengumpul jagung (PPJ) yang berada di tingkat desa/kecamatan dan dua pedagang besar yang berada di tingkat kabupaten/kota. Pengambilan sampel pedagang dilakukan dengan metode snowball yaitu mengalir menurut informasi dari para petani dan para pedagang yang dapat memberikan informasi secara baik (akurat) menyangkut telaah terhadap efisiensi pemasaran maupun aspek kelembagaannya.

\section{Metode Analisis Data}

Untuk menjawab tujuan penelitian secara garis besar analisis data terdiri dari dua bagian yaitu analisis yang menyangkut efisiensi pemasaran dan analisis kelembagaan pemasaran. Analisis efisiensi pemasaran terdiri dari analisis marjin pemasaran, analisis farmer's share, dan analisis ratio keuntungan dan biaya pemasaran. Adapun analisis kelembagaan pemasaran menyangkut telaah terhadap aturan/norma yang terjadi dalam setiap pertukaran (transaksi ekonomi) antar lembaga pemasaran yang secara langsung maupun tidak langsung terkait dengan efisiensi dan efektivitas dalam pemasaran jagung. Pada analisis kelembagaan pemasaran ini, kajian terhadap biaya dan manfaat yang diperoleh pada setiap lembaga pemasaran tidak hanya didasarkan pada biaya dan manfaat secara partial namun sesuai dengan philosifi kajian kelembagaan penilaian terhadap biaya dan manfaat dilihat sebagai keseluruhan. Hal ini selaras dengan fokus kajian kelembagaan yang lebih bersifat "keseluruhan" (holism) dibandingkan dengan kajian ekonomi neo klasik yang bersifat "sebagian" (particularism) (Yustika, 2006).

\section{a). Analisis Marjin Pemasaran}

Marjin pemasaran didefinisikan sebagai perbedaan harga yang diterima oleh petani dengan harga yang dibayarkan oleh konsumen akhir. Pada suatu saluran pemasaran tertentu biasanya terdapat beberapa lembaga pemasaran yang terlibat misalnya pedagang pengumpul di tingkat desa/kecamatan, pedagang besar di tingkat kabupaten/provinsi, dan pedagang pengecer. Oleh karena itu, secara umum untuk menghitung marjin pemasaran digunakan rumus sebagai berikut: 
$\mathrm{Mp}=\mathrm{Pr}-\mathrm{Pf}$ atau

$\mathrm{Mpi}=\mathrm{Bpi}+\mathrm{Kpi}$

Sehingga marjin pemasaran total merupakan penjumlahan dari marjin pemasaran pada setiap tingkat lembaga pemasaran ke-i atauMp $=\sum$ Mpi

Keterangan:

$\mathrm{Mp}=$ Marjin pemasaran total

Mpi = Marjin pada lembaga pemasaran ke-i

$\mathrm{Pr}=$ Harga di tingkat konsumen

$\mathrm{Pf}=$ Harga di tingkat petani

Bpi = Biaya pada lembaga pemasaran ke-i

$\mathrm{Kpi}=$ Keuntungan pada lembaga pemasaran ke-i berikut:

Adapun pengukuran unit penjualan dalam analisis pemasaran ini dilakukan sebagai

a. Marjin pemasaran dihitung berdasarkan perbedaan harga beli dengan harga jual dalam satuan rupiah tiap kilogram jagung kering pipil.

b. Tingkat harga beli dihitung berdasarkan harga rata-rata pembelian tiap kilogram jagung kering pipil.

c. Tingkat harga jual dihitung berdasarkan harga rata-rata penjualan tiap kilogram jagung kering pipil.

b). Analisis Farmer's Share dan Ratio Keuntungan dengan Biaya Pemasaran

Analisis farmer's share digunakan untuk mengetahui bagian harga yang diterima petani dari keseluruhan harga yang dibayarkan konsumen akhir yang dinyatakan dalam persen. Berkaitan dengan hal ini, analisis farmer's share sering dilakukan untuk menilai apakah kinerja pemasaran telah berlangsung efisien atau tidak. Terdapat kriteria bahwa apabila share keuntungan dari tiap lembaga yang terlibat dalam proses pemasaran relatif merata, maka sistem pemasaran dapat dikatakan efisien. Kriteria lain yaitu apabila share ratio keuntungan dengan biaya pemasaran pada tiap lembaga yang terlibat dalam proses pemasaran relatif merata dan atau mencerminkan balas jasa yang adil (logis), maka sistem pemasaran dapat dikatakan efisien. Merujuk pada kriteria efisiensi tersebut maka bagian harga yang diterima petani (farmer's share) seharusnya memperoleh proporsi terbesar mengingat pengorbanan yang dilakukan cenderung lebih besar dibandingkan lembaga pemasaran lainnya dalam keseluruhan penyediaan barang yang diperdagangkan (Hanafiah dan Saefuddin, 1986). Farmer's share untuk komoditas jagung dapat dirumuskan sebagai berikut:

Fs $=\frac{P f}{P r} \times 100 \%$

Keterangan :

Fs $=$ Farmer's share

$\mathrm{Pf}=$ Harga di tingkat petani $(\mathrm{Rp} / \mathrm{Kg})$ 
$\mathrm{Pr}=\mathrm{Harga}$ di tingkat konsumen $(\mathrm{Rp} / \mathrm{Kg})$

Adapun analisis terhadap share biaya pemasaran dan share keuntungan yang juga digunakan untuk menilai efisiensi pemasaran dapat diformulasikan sebagai berikut:

$\mathrm{SKi}=\frac{\mathrm{Ki}}{\mathrm{Pr}-\mathrm{Pf}} \times 100 \%$

$\mathrm{SBi}=\frac{\mathrm{Bi}}{\mathrm{Pr}-\mathrm{Pf}} \times 100 \%$

Keterangan:

SKi $=$ Share keuntungan lembaga pemasaran ke-i

$\mathrm{SBi}=$ Share biaya lembaga pemasaran ke- $\mathrm{i}$

Oleh karena itu, ratio keuntungan terhadap biaya pemasaran selanjutnya dapat dirumuskan sebagai berikut:

Ratio $(K / B) \mathrm{i}=\frac{\mathrm{SKi}}{\mathrm{SBi}} \times 100 \%$

Keterangan:

Ratio $(\mathrm{K} / \mathrm{B}) \mathrm{i}=$ Ratio keuntungan dan biaya pada tiap lembaga pemasaran ke-i.

\section{ANALISIS DAN PEMBAHASAN}

\section{Saluran dan Kelembagaan Pemasaran}

Kegiatan pendistribusian hasil panen jagung dari petani ke konsumen khususnya di Kecamatan Tujuh Belas Kabupaten Bengkayang dilakukan melewati beberapa lembaga pemasaran. Secara berjenjang, terdapat tiga lembaga utama dalam pemasaran jagung di lokasi ini, yaitu: petani, pedangan pengumpul jagung (PPJ) atau pedagang desa, dan pedagang besar. Mempelajari keseluruhan rangkaian dalam pemasaran jagung tersebut, peranan PPJ sangat menonjol dalam menjaga keberlangsungan usahatani jagung di tingkat petani. PPJ sangat besar peranannya dalam usahatani jagung di daerah ini mengingat PPJ tidak hanya berperan dalam pendistribusian jagung ke konsumen namun juga dalam penyediaan sarana produksi yang diperlukan petani. Pada kegiatan produksi, di satu sisi, PPJ memberi pinjaman kepada para petani berupa sarana produksi seperti benih, pupuk, dan obat-obatan. Pada sisi lainnya, PPJ juga berperan sebagai lembaga pemasaran yakni menampung jagung yang diproduksi oleh para petani. Demikian pentingnya peranan PPJ, sehingga model hubungan kelembagaan yang terjadi dapat disejajarkan sebagai model contract farming yang dijalan secara informal (informal contract farming). Secara skematik hubungan kelembagaan dalam pendistribusian jagung dapat diilustrasikan pada Gambar 1. 


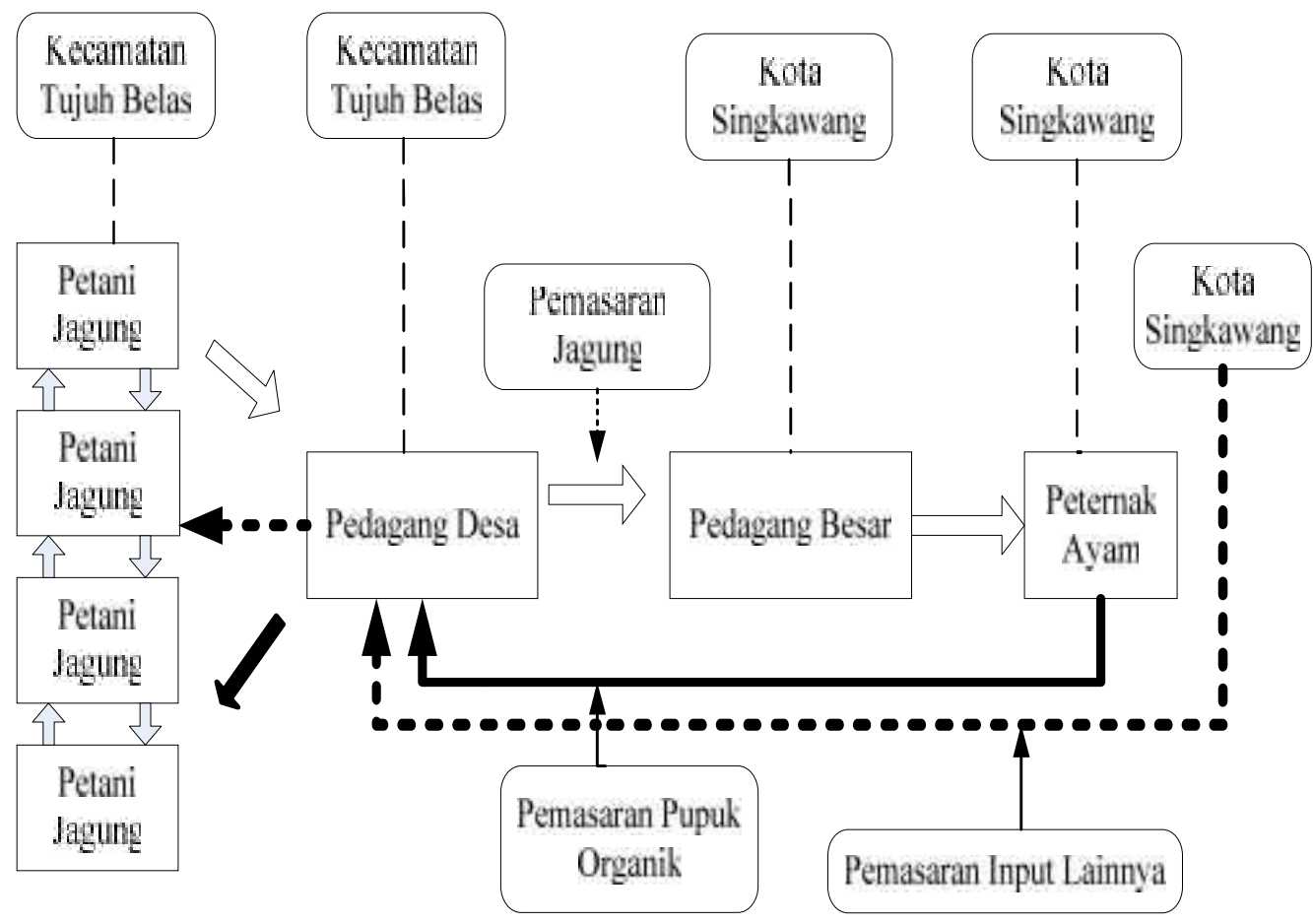

Gambar 1. Skema Hubungan antar Lembaga Pemasaran dalam Agribisnis Jagung di Kecamatan Tujuh Belas Kabupaten Bengkayang.

Berdasarkan pada Gambar 1 di atas, tampak bahwa hubungan kelembagaan dalam kegiatan produksi dan pemasaran jagung di daerah ini dapat diidentifikasi ke dalam tiga bagian, yaitu: (a) hubungan petani dengan PPJ, (b) PPJ dengan pedagang besar, dan (c) pedagang besar dengan peternak ayam. Di tingkat desa, hubungan petani dengan PPJ dapat diketegorikan sebagai hubungan yang bersifat patron-client, sehingga terlihat dengan jelas bahwa peranan PPJ sangat menentukan dan penting dalam keseluruhan rangkaian hubungan kelembagaan di atas, peranan PPJ terlihat tidak hanya dalam pendistribusian hasil panen jagung berupa jagung pipilan untuk pakan ternak ayam, melainkan juga dalam pemberian pinjaman input usahatani jagung yaitu berupa pinjaman pupuk organik yang berasal dari kotoran ayam (TA), pupuk anorganik (Urea, TSP, KCl, Phonska), dan obatobatan (herbisida, insektisida). Untuk keberlanjutan usahatani penyediaan pupuk organik ini sangat penting dilihat dari aspek menjaga stabilitas kesuburan lahan usahatani, mengingat usahatani jagung di daerah ini dapat dilakukan secara terus menerus sepanjang tahun (bisa tiga kali musim tanam setahun). Selanjutnya, pinjaman input tersebut dibayar oleh para petani segera setelah panen, yaitu ketika jagung yang dihasilkan dijual kepada PPJ.

Hubungan kelembagaan berupa kerjasama (kemitraaan) antara petani dengan PPJ di daerah ini sesungguhnya banyak didasarkan pada rasa saling percaya (mutual trust) dan norma timbal balik (reciprocity). PPJ memberikan pinjaman input kepada para petani yang dipercayainya, sebaliknya petani membalas kebaikan PPJ dengan melakukan penjualan jagung yang diproduksinya. Dengan perkataan lain, hubungan kelembagaan ini banyak didasarkan pada penerapan nilai-nilai "social capital". Penerapan nilai-nilai social capital secara lebih mendalam terlihat dalam banyak aktivitas yang dilakukan, misalnya ketika penimbangan jagung, petani mempercayai sepenuhnya kepada kejujuran PPJ berserta karyawannya (petani jarang terlibat dalam penimbangan jagung kering pipilan di gudang 
PPJ), sebaliknya PPJ juga sangat mempercayai petani dalam kesetiaan penjualan jagung bahkan PPJ sering memberikan pinjaman tunai (cash loan) kepada para petani untuk berbagai keperluan petani baik untuk mengembangkan usahatani maupun keperluan sosial lainnya. Bekerjanya nilai dan norma seperti ini membuktikan bahwa social capital terbukti berperanan penting dalam menciptakan efisiensi perdagangan hasil pertanian, sebagaimana juga dilaporkan oleh Fafchamps and Minten (1999) dan Syahyuti (2008) bahwa pedagang hasil pertanian umumnya menggunakan social capital dalam upaya mengurangi biaya pengawasan dan biaya pencarian dalam banyak transaksi yang dilakukan di perdesaan.

Demikian pula pada hubungan PPJ dengan pedagang besar, setiap pelaku dalam kelembagaan pemasaran ini menjalankan peranannya masing-masing. Pedagang besar memiliki kedudukan penting yakni sebagai lembaga yang berperanan menjaga stabilitas pembayaran jagung kepada pedagang pengumpul atau secara tidak langsung kepada petani, sebab menurut keterangan beberapa PPJ penjualan jagung secara langsung kepada peternak ayam (tanpa melewatipedagang besar) sering ditunda waktu pembayarannya. Penundaan pembayaran terjadi karena peternak ayam kadang-kadang kehabisan cadangan uang tunai yang disebabkan adanya keterlambatan pembayaran dari hasil penjualan telur yang diproduksinya. Pedagang besar dengan kemampuan keuangan yang sangat besar mampu mengatasi adanya masalah ini sehingga kelancaran pembayaran kepada PPJ dan petani dapat dijamin.

Pada keseluruhan kelembagaan pemasaran jagung di atas, terdapat kesetiaan penjualan jagung dari petani kepada PPJ, demikian pula dari PPJ kepada pedagang besar. Artinya setiap petani sudah memiliki mitra PPJ tertentu dan setiap PPJ juga sudah memiliki mitra pedagang besar tertentu yang mampu menjaga kelancaran pembayaran. Pada sisi lainnya, pedagang besar juga sudah memiliki peternak ayam tertentu yang menjadi langgannya. Melalui mekanisme berlangganan setiap lembaga memiliki kepastian atau jaminan dalam setiap penjualan barang dagangannya. Bagi peternak ayam, sistem kelembagaan yang terbentuk ini juga memberikan jaminan atau kepastian dalam penjualan hasil ikutan dari usaha ternaknya yaitu penjualan pupuk organik yang berasal dari kotoran ayam (TA). Dengan demikian, secara keseluruhan model kelembagaan agribisnis ini dapat juga dipandang sebagai model integrasi pengembangan jagung dengan unggas yang relatif baik.

\section{Efisiensi Pemasaran}

Sebagaimana telah dikemukakan di atas bahwa efisiensi pemasaran dapat dikaji dari marjin pemasaran, besarnya share harga yang diterima oleh masing-masing lembaga pemasaran, dan juga share ratio keuntungan dengan biaya pemasaran. Marjin pemasaran pada satu sisi dipengaruhi oleh panjang pendeknya saluran pemasaran, aktivitas-aktivitas yang dilakukan dalam pendistribusian barang, dan keuntungan yang diharapkan oleh setiap lembaga pemasaran, sedangkan pada sisi lainnya juga dipengaruhi oleh nilai dan norma sosial (social capital) yang berlaku dalam hubungan kerjasama atau kemitraan. Tabel 2 berikut ini memperlihatkan hasil analisis marjin, distribusi marjin, share harga yang diterima lembaga pemasaran serta ratio keuntungan dengan biaya pemasaran dalam pemasaran jagung. 
Tabel 2. Marjin pemasaran, distribusi marjin, dan share harga yang diterima tiap lembaga pemasaran serta ratio keuntungan dengan biaya dalam pemasaran jagung di Kabupaten Bengkayang.

\begin{tabular}{|c|c|c|c|c|}
\hline $\begin{array}{l}\text { Lembaga pemasaran dan komponen } \\
\text { marjin }\end{array}$ & $\begin{array}{c}\text { Biaya dan } \\
\text { harga }(\mathrm{Rp} / \mathrm{kg})\end{array}$ & $\begin{array}{l}\text { Distribusi } \\
\text { marjin (\%) }\end{array}$ & $\begin{array}{c}\text { Share } \\
\text { harga }(\%)\end{array}$ & $\begin{array}{l}\text { Ratio } \\
(\mathrm{K} / \mathrm{B}) \mathrm{i}\end{array}$ \\
\hline \multicolumn{5}{|l|}{ Petani } \\
\hline Biaya usahatani**) & 1403 & & & 1,14 \\
\hline Harga jual & 3000 & & 76,92 & \\
\hline Keuntungan & 1597 & & & \\
\hline \multicolumn{5}{|l|}{$\begin{array}{l}\text { Pedagang Pengumpul Jagung } \\
\text { (PPJ) }\end{array}$} \\
\hline Biaya transportasi panen & 60,83 & 6,76 & 1,56 & \\
\hline Biaya pengeringan & 70 & 7,78 & 1,79 & \\
\hline Biaya bongkar muat & 50 & 5,56 & 1,28 & \\
\hline Biaya transportasi penjualan jagung & 141,67 & 15,74 & 3,63 & \\
\hline $\begin{array}{l}\text { Biaya pemasaran total di PPJ } \\
\text { Harga beli }\end{array}$ & $\begin{array}{l}322,50 \\
3000\end{array}$ & 35,83 & $\begin{array}{r}8,27 \\
76,92\end{array}$ & 0,55 \\
\hline Harga jual & 3500 & & 89,74 & \\
\hline Keuntungan & 177,50 & 19,72 & 4,55 & \\
\hline \multicolumn{5}{|l|}{ Pedagang Besar } \\
\hline Harga beli & 3500 & & 89,74 & \\
\hline Harga jual & 3900 & & & \\
\hline Keuntungan & 400 & 44,44 & & \\
\hline Total margin pemasaran & 900 & & & \\
\hline
\end{tabular}

Sumber: Data primer (Data diolah, 2013).

Catatan: $\left.{ }^{* \star}\right)$ Biaya usahatani sudah termasuk biaya pasca panen yang menjadi tanggungan petani.

Memperhatikan Tabel 2 di atas, dilihat dari distribusi marjin tampak bahwa keuntungan paling besar dinikmati oleh pedagang besar $(44,44 \%)$, sedangkan keuntungan yang diterima oleh PPJ relatif lebih kecil (19,72\%). Besarnya keuntungan pedagang besar ini dikarenakan mengeluarkan biaya pemasaran yang lebih sedikit sementara itu dapat menjual jagung kepada para peternak ayam dengan harga yang lebih tinggi. Pada Tabel 2 di atas tidak dapat ditampilkan biaya riil yang dikeluarkan oleh pedagang besar, karena sesungguhnya dalam pemasaran jagung di daerah ini peranan pedagang besar hanya sebagai perantara saja. Peranan utama pedagang besar adalah dalam memperlancar pembayaran tunai akibat adanya penundaan pembayaran yang sering dilakukan oleh para peternak ayam. Penundaan pembayaran oleh peternak ayam sering dilakukan karena ketersediaan uang peternak biasanya menunggu dari hasil penjualan telur. Pedagang besar dengan kemampuan keuangan yang juga besar mampu memainkan peranan pembayaran langsung ini dengan baik. Dengan perkataan lain tanpa adanya peran pedagang besar, sulit dilakukan pembayaran jagung secara tepat waktu oleh peternak kepada PPJ dan sekaligus juga kepada para petani yang ada di desa. Menurut keterangan para PPJ, setiap melakukan pengiriman jagung ke pedagang besar selalu diperintahkan membongkar jagung yang dikirim tersebut di lokasi peternakan ayam yang menjadi mitra pedagang besar. Truk pengangkut 
jagung tersebut pada saat pulang diisi dengan pupuk organik kotoran ayam (TA) dan kemudian PPJ atau sopir truk yang menjadi utusan PPJ mampir di kantor pedagang besar untuk menerima pembayaran jagung. Pada saat pembayaran jagung ini langsung dikurangi dengan nilai pupuk organik kotoran ayam yang dibawa PPJ.

Dilihat dari share harga yang diterima petani (farmer's share) yaitu sebesar 76,92 persen, memperlihatkan bahwa kelembagaan pemasaran telah memberikan harga yang cukup tinggi kepada petani, sehingga dapat dikatakan bahwa bagian harga ini telah cukup adil dan logis yang memperlihatkan bahwa kelembagaan pemasaran telah berjalan efisien. Dengan demikian, kelembagaan pemasaran ini dapat mendorong peningkatan produksi lebih lanjut oleh para petani yang berada di wilayah perdesaan. Demikian pula dilihat dari ratio keuntungan dan biaya yang dikeluarkan, apabila dibandingkan antara petani dengan PPJ, ratio keuntungan dan biaya yang lebih besar dinikmati oleh petani yaitu sebesar 1,14, sedangkan di tingkat PPJ hanya sebesar 0,55. Rendahnya keuntungan yang diperoleh PPJ tidak berarti PPJ tidak memperoleh manfaat yang besar dalam kelembagaan pemasaran ini. Dilihat dari analisis biaya dan manfaat secara keseluruhan (totalitas), PPJ tetap memperoleh manfaat atau keuntungan yang cukup besar dalam kerja sama produksi dan sistem kelembagaan pemasaran ini, yaitu dari volume penjualan jagung serta dari penjualan input/sarana produksi usahatani jagung (TA, Urea, TSP, KCl, Phonska, herbisida, insektisida, benih jagung, dll.) yang dijual kepada para petani yang menjadi mitranya (Tabel 3).

Tabel 3. Harga Beberapa Sarana Produksi Pertanian di tingkat PPJ.

\begin{tabular}{lcc}
\hline \multicolumn{1}{c}{ Jenis sarana produksi } & $\begin{array}{l}\text { Harga pinjaman dari PPJ dengan } \\
\text { jangka waktu pengembalian sekitar } \\
4 \text { bulan }\left(\text { Rp/karung }{ }^{\star *}\right)\end{array}$ & $\begin{array}{c}\text { Harga kontan } \\
\text { (Rp/karung) }\end{array}$ \\
\hline $\begin{array}{l}\text { Pupuk organik dari kotoran } \\
\text { ayam (TA) }\end{array}$ & $18000-20000$ & $15000-18000$ \\
Urea & $110000-115000$ & 100000 \\
TSP & $135000-140000$ & 130000 \\
Phonska & $135000-140000$ & 130000
\end{tabular}

Sumber: Data Primer

Catatan: ${ }^{* *}$ ) Tiap karung TA beratnya 20 kg, sedangkan tiap karung Urea, TSP, dan Phonska beratnya $50 \mathrm{~kg}$.

Berpedoman pada Tabel 3 di atas, apabila tiap hektar petani menggunakan pupuk TA sebanyak 40 karung, Urea 4 karung, TSP 1 karung, maka keuntungan PPJ dari penjualan sarana produksi usahatani ini bisa mencapai Rp. 150.000/petani/musim tanam bahkan lebih besar lagi, karena ditambah keuntungan dari penjualan herbisida, benih jagung unggul dan pupuk Phonska yang kadang-kadang digunakan oleh petani. Oleh karena itu, berdasarkan pada analisis penampilan kelembagaan pemasaran secara keseluruhan, maka dapat disimpulkan bahwa pemasaran jagung di Kecamatan Tujuh Belas Kabupaten Bengkayang telah berjalan cukup efisien. Hal ini dilihat dari share harga yang diterima oleh petani yang relatif besar (76,92 persen) dan fakta bahwa setiap lembaga pemasaran telah memperoleh manfaat yang logis sesuai dengan peranannya. 


\section{KESIMPULAN DAN IMPLIKASI KEBIJAKAN}

\section{Kesimpulan}

Berdasarkan pada analisis dan pembahasan di atas maka dapat dirumuskan beberapa kesimpulan hasil studi sebagai berikut:

(a) Hubungan antar lembaga dalam pemasaran jagung di Kecamatan Tujuh Belas Kabupaten Bengkayang banyak didasarkan penerapan nilai dan norma sosial (social capital) yang berperanan penting dalam meningkatkan efisiensi dan efektivitas keseluruhan kelembagaan pemasaran.

(b) Berdasarkan analisis biaya dan manfaat secara keseluruhan (totalitas) pada tiap lembaga pemasaran yang terlibat, maka dapat disimpulkan bahwa pemasaran jagung di Kecamatan Tujuh Belas Kabupaten Bengkayang telah berjalan cukup efisien. Hal ini dilihat dari share harga yang diterima oleh petani yang relatif besar (76,92 persen) dan fakta bahwa setiap lembaga pemasaran telah memperoleh manfaat yang logis sesuai dengan peranannya.

\section{Implikasi Kebijakan}

Berdasarkan pada temuan hasil penelitian ini, maka berbagai pihak termasuk instansi terkait di Kabupaten Bengkayang perlu menciptakan iklim yang kondusif dengan melakukan pembinaan terhadap petani maupun pedagang guna memelihara eksistensi social capital yang selama ini banyak mempengaruhi berbagai bentuk transaksi baik dalam kegiatan produksi maupun pemasaran jagung.

\section{DAFTAR PUSTAKA}

BPS, 2013. Kecamatan Tujuh Belas dalam Angka. BPS Kabupaten Bengkayang.

Burhansyah R., 2006. Model Pengembangan Agribisnis Berbasis Jagung Kawasan Usaha Agribisnis Terpadu Sanggau Ledo Kabupaten Bengkayang. Humanity 1(2): 87-95.

Fafchamps, M. and B. Minten, 1999. Social Capital and the Firm: Evidence from Agricultural Trader. Working Paper No. 17, September, pp 1-33, The World Bank Washington DC: Social Capital Iniciative.

Hanafiah, A.M. dan Saefuddin, A.M., 1986. Tataniaga Hasil Perikanan. Universitas Indonesia Press. Jakarta.

Mubyarto, 1989. Pengantar Ekonomi Pertanian.Cetakan ke Sembilan. Lembaga Penelitian, Pendidikan dan Penerangan Ekonomi dan Sosial (LP3ES). Jakarta.

Syahyuti, 2008. Peran Modal Sosial (Social Capital) dalam Perdagangan Hasil Pertanian. Forum Penelitian Agro Ekonomi 26 (1): 32-43.

Yustika, A. E., 2006. Ekonomi Kelembagaan, Definisi, Teori dan Strategi. Cetakan Pertama. Bayu Media. Malang. 